\title{
VÝSLEDKY VRTNÉHO PRŮZKUMU NA LOKALITĚ HOLUBICE (SPODNOBADENSKÉ SEDIMENTY KARPATSKÉ PŘEDHLUBNĚ)
}

\author{
Results of the drilling survey on the locality Holubice (Early Badenian, Carpathian Foredeep) \\ Slavomír Nehyba', Václav Zborník', Vladimíra Jašková2 \\ 'Ústav geologických věd, PřF MU, Kotlářská 2, 61137 Brno; e-mail: slavek@sci.muni.cz \\ ${ }^{2}$ Muzeum Prostějovska, náměstí T. G. Masaryka 2, 79601 Prostějov
}

(24-43 Šlapanice)

Key words: Carpathian Foredeep, Early Badenian, depositional environment, provenance

\begin{abstract}
Early Badenian deposits of the Carpathian Foredeep were newly studied in the sedimentary successions from drill holes Holubice 1 and Holubice 2. Facies analysis together with study of grain size, the shape and roundness of the coarsest grains, the mineral compositions of selected heavy minerals (garnet, rutile) and the gamma-ray spectra, were all used for better understanding the depositional setting and provenance. Studied sediments were deposited in coastal and shallow marine environments. Six lithofacies was recognised in the sedimentary succession in the drill holes. They have been combined into two facies associations - lower clastic one and upper carbonate one, reflecting deposition in shallow marine settings, upward shallowing trend and reduction of siliciclastic input. The primary source of the material is located mainly in the metamorphic rocks (gneisses, amphibolites and granulites). The spectral gamma-ray logs show vertical organization, which is consistent with the facies analysis and partly also grain-size. A significant reduction of terrigenous input is connected with deposition of carbonates (sandy limestones) in the upper part of the succession.
\end{abstract}

Úvod

Spodnobadenským sedimentům karpatské předhlubně byla $\mathrm{v}$ poslední době věnována zvýšená pozornost díky odvrtání celé řady vrtů (Nehyba - Jašková 2012; Zágoršek et al. 2012; Zborník et al. 2013). Byla tak získána řada nových informací týkajících se nejen místních geologických poměrů, ale také vývoje sedimentace a pozice řasových vápenců v rámci sedimentárního sledu. Díky vrtnému průzkumu hrazenému z grantového projektu GA ČR 205/09/0103 s názvem „Mělkovodní ekosystémy středního miocénu Centrální Paratethydy: Sukcese a interakce anorganické a organické složky ekosystémü“ byly provedeny

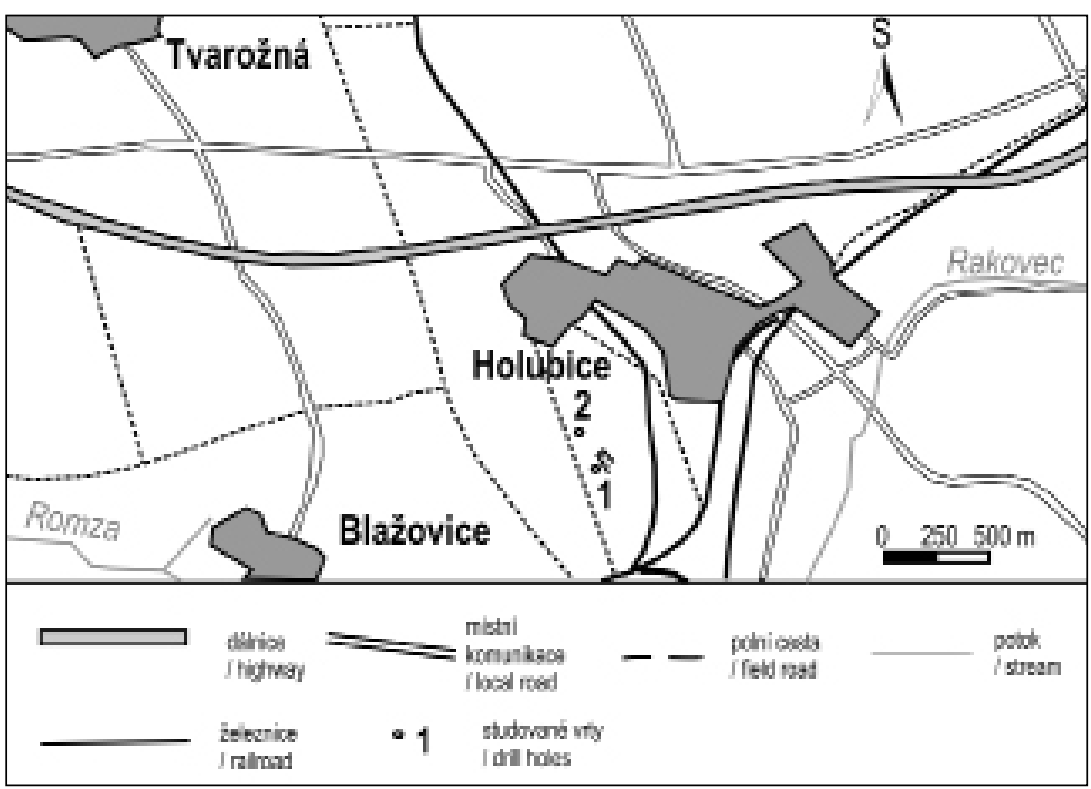

Obr. 1: Lokalizace zájmové oblasti.

Fig.1: Location of the area under study. dva vrty v okolí obce Holubice nedaleko Brna. Pozice vrtů je prezentována na obrázku 1. Sedimentárně-petrografické zhodnocení těchto vrtů je cílem předloženého př́ispěvku.

\section{Geologická stavba zájmové oblasti}

Zájmová oblast leží př̀ z. okraji spodnobadenské karpatské předhlubně. Předneogenní podloží je ve studované oblasti tvořeno spodnokarbonskými kulmskými horninami Drahanské vrchoviny (Mísař et al. 1983; Stráník et al. 1985). Řasové vápence v okolí Holubic popisuje Paulík (1953), který uvádí „větší množství lumkủ v různém stavu těžby“. Cicha (1962) konstatuje v rámci mapovacích sond další podpovrchové výskyty řasových vápenců. Novák (1975) uvádí již pouze dva existující odkryvy pobliž kóty $286,6 \mathrm{~m} \mathrm{n}$. m. V současnosti jsou tyto bývalé těžebny $\mathrm{v}$ naprosté většině zavezeny a terén je zarovnán. V podloží řasových vápenců jsou popsány vápnité spodnobadenské jíly, v nadloží se vyskytují spraše (Paulík 1953; Novák 1975). Spodnobadenské řasové vápence jsou zde proměnlivě písčité, středně až hrubě zrnité, často se stř́dající s polohami silně vápnitých pískovců. Výše zmínění autoři konstatují, že na složení organodetritických vápenců se podílejí převážně vápnité stélky červených řas, mechovky a měkkýši. $\mathrm{V}$ menší míre jsou zastoupeny foraminifery, ostny ježovek, vzácněji korálové trsy. Schránky jsou obvykle značně rozlámány. Kalcitový tmel tvoří 
kolem $45 \%$ celkového objemu horniny. Klastická složka je tvořena převážně křemenem, méně draselnými živci. Zrna křemene jsou obvykle ostrohranná, nepravidelného tvaru o velikosti do $1 \mathrm{~mm}$. V asociaci těžkých minerálů naprosto dominuje granát (57,3\%), výrazněji je zastoupen také zirkon (25,6\%), dále byl zjištěn rutil $(9,4 \%)$, staurolit $(2,6 \%)$, disthen $(3,4 \%)$ a turmalín (1,7\%). Podíl stabilních těžkých minerálů je relativně vysoký (ZTR index 36,7 \%). Zrna granátů jsou nejčastěji ostrohranná až polozaoblená, nepravidelného tvaru a dosahují velikosti do $0,5 \mathrm{~mm}$. Zirkon je převážně sloupcovitý či eliptický. Izometrická zrna jsou méně hojná. Velikost zirkonu dosahuje maximálně 0,35 mm. Zonální zirkony jsou vzácné (Novák 1975).

\section{Metodika}

Litofaciální analýza byla provedena dle zásad uvedených v pracích Tuckera (1988), Walkera a Jamese (1992) a Nemece (2005). Tvar a zaoblení nejhrubší frakce (> $4 \mathrm{~mm}$ ) byly určeny vizuálně s pomocí metody Powerse (1982). Zrnitostní analýza byla realizována kombinovanou metodou normovaných sít („za mokra“) a laserové difrakce (Retsch AS 200 sítovací analyzátor a Cilas 1064 laserový granulometr). K určení zrnitostních charakteristik (Mz, $\sigma \mathrm{I})$ byly využity vzorce dle Folka a Warda (1957). Studium petrografického složení frakce nad $2 \mathrm{~mm}$ proběhlo $\mathrm{v}$ jednotlivých vzorcích v populaci 3-200 zrn. Těžké minerály byly studovány v zrnitostní frakci $0,063-0,125 \mathrm{~mm}$. Chemismus granátu (30 analyzovaných zrn) a rutilu (10 zrn) byl posouzen ve dvou vzorcích (Holubice $1-7,40 \mathrm{~m}$, Holubice $2-9,50 \mathrm{~m}$ ) a to na mikrosondě Cameca SX 100 (Společná laboratoř MU a ČGS Brno). Gamaspektrometrická analýza byla provedena na GR-320 enviSPEC laboratorním spektrometru (Exploranium, Canada) na ÚGV PřF MU v Brně. Gamaspektrometrickou analýzou bylo vyhodnoceno 29 vzorků (vrt Holubice 1 - 13 vzorků, vrt Holubice 2 - 16 vzorků). Hmotnost vzorků se pohybovala kolem $300 \mathrm{~g}$, doba měření byla 30 minut.

\section{Výsledky}

Na základě podrobného studia jader bylo vyčleněno 6 litofacií (M1, M2, Sm, Sl, Sv, Lp). Stručný popis litofacií je prezentován $\mathrm{v}$ tabulce 1 . Zrnitostní a petrografické charakteristiky byly rozhodující při identifikaci litofacií. Role primárních sedimentárních struktur byla menší vzhledem $\mathrm{k}$ jejich částečné destrukci, která byla způsobena technologií vrtání. Na základě prostorové distribuce a depozičních procesů byly litofacie seskupeny do dvou faciálních asociací. Distribuci litofacií i faciálních asociací lze v rámci vrtných profilů sledovat na obrázcích 2 a 3 . Přes relativní blízkost vrtů není zastoupení jednotlivých litofacií ve vrtech zcela identické. Báze neogenních sedimentů nebyla vrty zastižena.

Spodní faciální asociaci FA 1 tvoří čtyři litofacie (M1, $\mathrm{M} 2, \mathrm{Sm}$ a Sl). V obou vrtech lze jednoznačně sledovat nahoru hrubnoucí trend, který odráží nárůst zastoupení písčité frakce směrem vzhůru. Nejnižší části faciální asociace jsou tvořeny rezavě smouhovaným vápnitým prachovitým jílem až jílovitým prachem se špatně zachovalou planární laminací se vzácnou příměsí drobných vápnitých konkrecí.
Tab. 1: Litofacie ve vrtech Holubice 1 a 2 a jejich základní charakteristika.

Tab. 1: List of facies in the wells Holubice 1 and Holubice 2.

\begin{tabular}{|c|c|}
\hline Symbol & Popis \\
\hline M1 & $\begin{array}{l}\text { Sytě šedohnědý až šedozelený místy rezavě smouhovaný } \\
\text { jílovitý prach, masivní, vápnitý. } \mathrm{Mz}=0,06 \mathrm{~mm} \text {. }\end{array}$ \\
\hline M2 & $\begin{array}{l}\text { Špinavě světle hnědošedý a zelenošedý, hnědě či rezavě } \\
\text { smouhovaný, světle olivově zelený, jílovitý prach, vápnitý, } \\
\text { úlomky schránek, proměnlivě bioturbovaný. Proměnlivě } \\
\text { písčitý, více písčité partie vykazují špatně zachovanou pla- } \\
\text { nární laminaci. Vzácně drobné Ca konkrece. } \mathrm{Mz}=0,06- \\
0,01 \mathrm{~mm} \text {. }\end{array}$ \\
\hline $\mathrm{Sm}$ & $\begin{array}{l}\text { Bělavě šedý sytě šedě smouhový nebo až žlutošedý rezavě } \\
\text { smouhovaný jílovito-prachovitý písek, v rámci písčité frak- } \\
\text { ce dominuje velmi jemnozrnný písek, přítomnost útržkủ a } \\
\text { mázder zelenošedého jílovce. Místy úlomky schránek, vel- } \\
\text { mi proměnlivá bioturbace (v mocnějších polohách), zbytky } \\
\text { planární laminace. } \mathrm{Mz}=0,06 \mathrm{~mm} \text {. }\end{array}$ \\
\hline $\mathrm{Sl}$ & $\begin{array}{l}\text { Světle zelenožlutý šedý až bělavě žlutohnědý prachovitý pí- } \\
\text { sek, v rámci písčité frakce naprosto dominuje jemnozrnný } \\
\text { až velmi jemnozrnný písek, lokálně planární laminace, váp- } \\
\text { nitý, lokálně úlomky schránek (měkkýši, řasy), proměnlivá } \\
\text { bioturbace, slabě jemně slídnatý. } \mathrm{Mz}=0,12-0,42 \mathrm{~mm} \text {. }\end{array}$ \\
\hline $\mathrm{Sv}$ & $\begin{array}{l}\text { Rezavě žlutohnědý, žlutošedý, bělavě smouhovaný, pracho- } \\
\text { vitý písek, v rámci písčité frakce dominuje jemnozrnný pí- } \\
\text { sek, silně vápnitý, lokálně bioturbovaný, výskyt vápnitých } \\
\text { řas, nerovná báze i strop při přechodu do řasových vápencủ } \\
\text { facie L. Lokálně zachovaná planární laminace. Místy klasty } \\
\text { facie L. Mz }=0,1 \mathrm{~mm} \text {. }\end{array}$ \\
\hline Lp & $\begin{array}{l}\text { Bělavě šedý až bělavě hnědý písčitý vápenec až vápnitý pís- } \\
\text { kovec proměnlivě zpevněný, vysoké zastoupení vápnitých } \\
\text { ras, schránky měkkýšù, proměnlivě zachováno zvrstvení } \\
\text { (planární či mírně ukloněné, výrazné rozdíly v přítomnosti } \\
\text { písčité frakce i v její zrnitosti (až hrubozrnný písek, obvyk- } \\
\text { le relativně hrubozrnnější báze těles), řada nahoru zjemnnu- } \\
\text { jících cyklủ řádu dm. }\end{array}$ \\
\hline
\end{tabular}

Výše má sediment charakter velmi jemnozrnného až jemnozrnného vápnitého prachovitého písku s proměnlivou bioturbací a přítomností útržků mázder jílovce, úlomků schránek a vápnitých řas. Př́itomnost štěrkové frakce je velmi malá (tj. do $1 \%$ ) a tato je tvořena naprosto dominantně úlomky schránek (měkkýši, mechovky, řasy) a jen velmi vzácně poloostrohrannými zrnky křemene.

$\mathrm{V}$ rámci FA 1 bylo provedeno 17 gamaspektrometrických měření. Siliciklastické sedimenty FA 1 vykazují vcelku nízké hodnoty koncentrace $\mathrm{K}(0,87-2,12 \%$, průměrná hodnota /AVG/ byla 1,61\%). Koncentrace U byly relativně stálé (1,86-2,70 ppm, AVG 2,28 ppm), podobně jako koncentrace Th, které nabývají relativně vyšších hodnot (6,51-10,15 ppm, AVG 8,35 ppm). Lze generelně sledovat celkový pokles koncentrací $\mathrm{K}$ a Th směrem vzhůru (s výjimkou nejvyšší partie FA 1 tvořené litofacií Sl), což vcelku odpovídá relativnímu nárůstu průměrné velikosti zrna. Průměrná hodnota poměru Th/U je středně vysoká $(3,85)$ a průměrná hodnota poměru $T h / K$ je vyšší $(5,61)$. Korelace mezi hodnotou celkové radioaktivity $\left(\mathrm{nGy}_{\mathrm{kg}}{ }^{-1}\right)$ a koncentracemi $\mathrm{K}$, Th a U ukazují, že hlavním nositelem přirozené radioaktivity jsou $\mathrm{K}(\mathrm{r}=0,84)$ a Th $(\mathrm{r}=0,53)$. Relativně menší roli hraje $U(r=0,13)$. Korelace $U$ a Th nabývá negativní hodnoty $(\mathrm{r}=-0,26)$, podobně jako korelace mezi U a K $(\mathrm{r}=-0,22)$, kdežto korelace $\mathrm{K}$ a Th je pozitivní a poměrně vysoká $(r=0,61)$. Záporná korelace byla zjištěna př̀i srovnání prrítomnosti jílové frakce a koncentrace $\mathrm{U}(\mathrm{r}=-0,37)$, kdežto pozitivní a poměrně vysoká korelace byla zjištěna při srovnání podílu jílové frakce $\mathrm{K}(\mathrm{r}=0,55)$, 

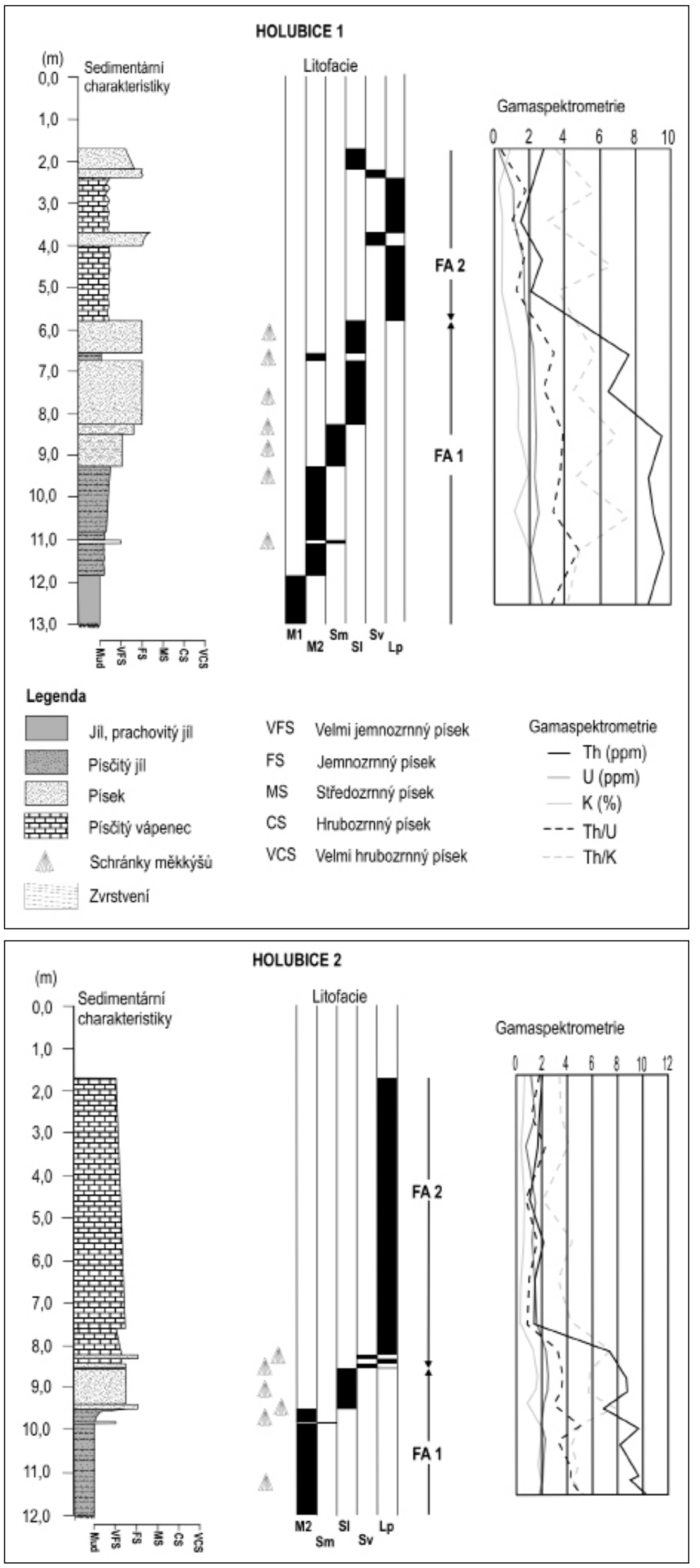

Obr. 2: Litologický profil vrtem Holubice 1 .

Fig. 2: Lithological logs of the wells Holubice 1; b - Holubice 2.

a také $\mathrm{Th}(\mathrm{r}=0,44)$. Slabě pozitivní korelaci vykazuje zastoupení písčité frakce s koncentrací $\mathrm{U}(\mathrm{r}=0,25)$ a naopak negativní korelace byla zjištěna při srovnání zastoupení písčité frakce a $\mathrm{K}(\mathrm{r}=-0,55)$, a také Th $(r=-0,47)$.

Svrchní faciální asociace FA 2 je tvořena dvěmi litofaciemi ( $\mathrm{Sv}$ a Lp), přičemž litofacie Lp výrazně dominuje. Písčité vápence a vápnité pískovce jsou velmi proměnlivě zpevněny, což $\mathrm{v}$ následné kombinace s technologií vrtání nedovolilo jednoznačně odlišit zastoupení planárního/horizontálního a ukloněného (šikmého?) zvrstvení v rámci profilu. Typický je výskyt vápnitých řas a schránek měkkýšů. Typické jsou značné rozdíly v zastoupení klastické (především písčité) a organodetritické komponenty, ve které dominují vápnité ráasy a schránky měkkýšů. Př́itomnost klastické štěrkové frakce byla proměnlivá a pohybovala se $\mathrm{v}$ prvních procentech. Maximální velikost zrn v A-ose byla zcela ojediněle $2,2 \mathrm{~cm}$, většinou nepřesahovala $1 \mathrm{~cm}$. Jednalo se převážně o klasty vápnitého pískovce, které byly převážně ostrohranné až poloostrohranné, méně často polozaoblené a zcela dominantně čepelovitého tvaru. Polozaoblené klasty křemene byly vzácnější a měly spiše kulovitý tvar.

Gamaspektrometrickou analýzou (12 měření) v rámci FA 2 bylo zjištěno, že sedimenty asociace FA 2 vykazují nízké a stabilní koncentrace K $(0,32-0,73 \%$, průměrná hodnota AVG 0,47\%), Th (0,94-2,79 ppm, AVG 1,83 ppm), a také U (0,09-1,60 ppm, AVG 1,21 ppm). Koncentrace prirozených radioaktivních prvků, především $K a T h$, jsou výrazně nižší než v rámci FA 1. Průměrná hodnota poměru $\mathrm{Th} / \mathrm{U}$ dosahuje 1,40 a průměrná hodnota poměru $\mathrm{Th} / \mathrm{K}$ je 3,97 .

Obr. 3: Litologický profil vrtem Holubice 2. Legenda viz obr. 2.

Fig. 3: Lithological logs of the well Holubice 2. Legends see Fig. 2. 
To jsou hodnoty nižší než v rámci FA 1, což je způsobeno zejména nízkými koncentracemi Th. Z korelace hodnoty celkové radioaktivity (nGy. $\mathrm{kg}^{-1}$ ) se zastoupením jednotlivých radioelementů vyplývá, že nejvýraznějším nositelem radioaktivity $\mathrm{v}$ daném sedimentu je Th $(\mathrm{r}=0,57)$. Nižší roli pro celkovou úroveň koncentrace přirozených radioaktivních prvků hraje $\mathrm{K}(\mathrm{r}=0,3)$ a především $\mathrm{U}(\mathrm{r}=0,11)$. Korelace U a Th je negativní $(\mathrm{r}=-0,32)$ podobně jako korelace $\mathrm{U}$ a $\mathrm{K}(\mathrm{r}=-0,60)$. Naproti tomu koncentrace $\mathrm{K}$ a Th vykazují pozitivní korelaci $(\mathrm{r}=0,42)$. Pozitivní korelace byla zjištěna při srovnání přítomnosti jílové frakce a koncentrací $U(\mathrm{r}=0,36)$, naopak negativní při srovnání $\mathrm{s}$ koncentrací $\mathrm{Th}(\mathrm{r}=-0,16)$ a především $\mathrm{K}(\mathrm{r}=-0,64)$. Zastoupení písčité frakce vykazuje pozitivní korelaci s koncentrací Th $(\mathrm{r}=0,36)$ a především $\mathrm{K}(\mathrm{r}=0,71)$, zatímco korelace $\mathrm{k} U$ je negativní $(\mathrm{r}=-0,59)$. Srovnání výsledků gamaspektrometrie a zrnitosti platí především pro facii Sv.

Chemické složení granátů bylo relativně pestré (tab. 2) s naprostou dominancí almandinové složky. Nejvýše zastoupené jsou pyrop-almandiny s $37 \%$, následují se $33 \%$ grossular-almandiny a grossular-pyrop-almandiny s $13 \%$.

Tab. 2: Typy granátu ve studovaných vzorcích.

Tab. 2: Garnet types of the studied samples.

\begin{tabular}{|l|c|}
\hline TYP GRANÁTU & $\%$ \\
\hline ALM(64-78) - GRS(11-25) & 33 \\
\hline $\operatorname{ALM}(58-59)-$ GRS(25) - SPS(10-11) & 7 \\
\hline $\operatorname{ALM}(51-76)-\operatorname{GRS}(12-25)-\operatorname{PRP}(10-21)$ & 13 \\
\hline $\operatorname{ALM}(51-85)-\operatorname{PRP}(11-43)$ & 37 \\
\hline $\operatorname{ALM}(71-73)-\operatorname{PRP}(11-13)-\operatorname{SPS}(10)$ & 3 \\
\hline $\operatorname{ALM}(62)-\operatorname{SPS}(24)-\mathrm{GRS}(10)$ & \\
\hline
\end{tabular}

Koncentrace hlavních diagnostických prvků v rámci analyzovaných zrn rutilu jsou vysoce proměnlivé. Všechny hodnocené rutily vykazují vyšší koncentrace Fe než 1000 ppm, přičemž rozsah hodnot se pohybuje mezi 1460 a 8610 ppm s průměrem 3476 ppm. Zastoupení Nb se pohybuje mezi 260 a 8550 ppm (průměr 3951 ppm), Cr mezi 70 a 4100 ppm (průměr 1006 ppm) a Zr mezi 100-7 290 ppm (průměr 1352 ppm). Hodnota logCr/Nb byla negativní v $90 \%$ hodnocených vzorků.

\section{Interpretace}

Depoziční prostředí lze v nejhlubší metráži obou vrtů spojit s převládající sedimentací ze suspenze a ukládání prachovitého jílu (facie M1, M2), jen občas přerušované trakčním přínosem písčitého materiálu. Takové podmínky sedimentace lze předpokládat $\mathrm{v}$ oblasti relativně hlubšího moře pod bází vlnění („offshore“). Na klidné podmínky depozice ukazuje i přítomnost neporušených schránek tenkostěnných měkkýšů a bioturbace. Směrem vzhůru lze předpokládat postupné změlčování, spojené s vyšším př́nosem klastického písčitého materiálu. $V$ písčitých faciích nebyly zjištěny znaky odrážející sedimentaci v rámci břežní zóny, pokládáme je proto za produkt sedimentace moře (spodní či stř̌ední část předbřeží). Sedimenty FA 1 odpovídají parasekvenci nebo její části (Emery - Myers 1996). Vysoká pozitivní korelace Th a K ukazuje na spo- lečný zdroj signálu, kdežto negativní korelace těchto dvou prvků s U ukazuje, že původ signálu U je odlišný. Původ signálu Th a K lze hledat především v rámci jílové frakce, kdežto původ signálu $U$ je spíše $\mathrm{v}$ rámci písčité komponenty. Signál K a Th je hledán v rámci jílových minerálů, lze uvažovat o vyšší roli kaolinitu, ovšem signál může být nesen více minerály. Je to však výrazný rozdíl proti výsledkům z vrtů na lokalitách Hluchov a Brus (Nehyba - Jašková 2012; Zborník et al. 2013), kdy v rámci stratigraficky a litologicky obdobných faciálních sledů byly zjištěny odlišné závislosti radioelementů na jílové frakce při přibližně stejných koncentracích $\mathrm{K}$, Th and U. Lokalita Holubice odpovídá distálnějším partiím sedimentární pánve, a proto mineralogické složení jílové frakce může být odlišné. Výkyvy v zastoupení Th a U odráží nejspíše proměnlivé zastoupení psamitické frakce a karbonátového materiálu.

Nástup karbonátové sedimentace, tedy FA 2, odráží výraznou změnu depozičních podmínek. Hranice mezi FA 1 a FA 2 je zřetelná výrazným poklesem koncentrací zejména $K$, Th a hodnot poměru Th/U i Th/K, kterou interpretujeme také jako odraz redukce př́nosu klastického materiálu. Také v rámci FA 2 lze uvažovat o společném zdroji signálu $\mathrm{K}$ a Th a rozdílném zdroji pro U. Zdroj signálu U lze hledat $v$ rámci jílové frakce, kdežto zdroj signálu $\mathrm{K}$ a Th $\mathrm{v}$ rámci frakce písčité, a to jak $\mathrm{v}$ rámci lehkých minerálů (klastické slídy/živce), tak i v rámci těžkých minerálů. Uran je v FA 2 relativně nabohacen vzhledem k ostatním nositelům přirozené radioaktivity, což je pro sedimenty s vyšším obsahem karbonátů typické (Langmuir - Herman 1980; Berstad - Dypvik 1982). Nejnižší koncentrace U, Th i hodnoty Th/U a Th/K leží v uvnitř FA 2. Výkyvy v zastoupení Th a K odráží nejspíše proměnlivé zastoupení psamitické frakce a tedy relativní rozdíly v zastoupení klastické a karbonátové komponenty. Tyto rozdíly lze nejspíše vysvětlit rozdíly v přínosu klastického materiálu, odrážejícími rozdílnou intenzitu zvětrávacích procesů (relativně aridnější a relativně humidnější periody). Sedimentace FA 2 probíhala $v$ mělkomořských až příbřežních podmínkách vzhledem k výrazné roli trakčního proudění. Občasné vložky písčitější facie ukazují na cyklické změny podmínek sedimentace, střídání podmínek vhodnějších a méně vhodných pro tvorbu řasových vápenců. Relativní rozdíly v zastoupení facie $S v$ v jednotlivých vrtech v rámci FA 2 (v rámci dominantní facie Lp) mohou odrážet vnitřní stavbu karbonátového tělesa nebo rozdílnou vzdálenost od okraje pánve. Vložky klastických sedimentů jsou známy také $\mathrm{z}$ řasových vápenců $\mathrm{v}$ Podbřežicích, kde v současnosti vystupuje jejich největší přirozený odkryv. Rozdílná je i celková mocnost FA 2 v jednotlivých vrtech Holubice.

„Primární“ zdroj granátu lze hledat v regionálně metamorfovaných horninách (rulách, amfibolitech a granulitech), což potvrzují i výsledky studia rutilu. Jeho původ lze hledat také především v metamorfitech, přičemž lze předpokládat výrazně vyšší zastoupení hornin metapelitických (90\%) než metamafických (10\%). Získané analýzy nepotvrdily původ rutilu z magmatických hornin (Zack et al. 2004a,b; Triebolt et al. 2005). Provenience rutilu je tedy odlišná od provenience tohoto minerálu ve spodno- 
badenských sedimentech na lokalitách Hluchov a Brus (Nehyba - Jašková 2012; Zborník et al. 2013).

Celkově lze ve vrtech Holubice 1 a 2 doložit relativní změlčení směrem vzhưru, tedy progradační trend. Takovou situaci lze z pohledu sekvenční stratigrafie nejspíše spojit s traktem vysoké hladiny. Ve vazbě k pozici spodnobadenských karbonátových těles karpatské předhlubně, tzv. řasových vápenců, ve vztahu $\mathrm{k}$ pohybu relativní mořské hladiny (Buday 1955; Cicha - Dornič 1960; Krystek - Tejkal 1968; Hladíková et al. 1992; Doláková et al. 2008) je často uvažováno o jejím relativním poklesu. V zájmovém prostoru jsou řasové vápence vyvinuty $\mathrm{v}$ nadloží spodnobadenských pelitů tzv. téglů, které představují především sedimenty centrálnějších částí pánve. Ve srovnání s dříve vrtně hodnocenými lokalitami, tj. Přemyslovice, Hluchov a Brus (Nehyba - Jašková 2012; Zágoršek et al. 2012; Zborník et al. 2013) nejsou v podloží vápenců vyvinuty sedimenty transgresivního traktu, což je způsobeno jinou pozicí v rámci depoziční pánve. Významnou redukci přínosu siliciklastického materiálu ve spojení s tvorbou těchto karbonátových těles však zjištujeme na všech těchto lokalitách i přes rozdílný faciální záznam.

\section{Poděkování}

Studium bylo prováděno v rámci grantu GA ČR 205/09/0103. Za laskavé posouzení príspèvku a pripomínky děkujeme recenzentưm Nele Dolákové a Ondřeji Bábkovi.

\section{Literatura}

Berstad, S. - Dypvik, H. (1982): Sedimentological evolution and natural radioactivity of Tertiary sediments from the central North Sea. - Journal of Petroleum Geology, 5, 77-88.

Cicha, I. (1962): Zpráva o výzkumech tercieru na listu Vyškov. - Zprávy o geologických výzkumech v roce 1961, 208-211.

Doláková, N. - Brzobohatý, R. - Hladilová, Š. - Nehyba, S. (2008): The red-algal facies of the Lower Badenian limestones of the Carpathian Foredeep in Moravia (Czech Republic). - Geologica Carpathica, 59, 133-146.

Emery, D. - Myers, K. J. (eds) (1996) : Sequence stratigraphy. - Blackewll Science, 1-297. Oxford.

Folk, R. L. - Ward, W. (1957): Brazos River bar: a study in the significance of grain-size parameters. - Journal of Sedimentary Petrology, 27, 3-26.

Force, E. R. (1980): The provenance of rutile. - Journal of Sedimentary Petrology, 50, 2, 485-488.

Langmuir, D. - Herman, J. S. (1980): The mobility of thorium in natural waters at low temperatures. - Geochimica et Cosmochimica Acta, 44, 1753-1766.

Mísař, Z. - Dudek, A. - Havlena, V. - Weiss, J. (1983): Geologie ČSSR I Český masiv. - 1-333. SNTL Praha.

Nemec, W. (2005): Principles of lithostratigraphic logging and facies analyses. - Institutt for geovitenskap, Uni. Bergen, 1-28.

Nehyba, S. - Jašková, V. (2012): Výsledky vrtného průzkumu na lokalitě Hluchov (sedimenty spodního badenu karpatské předhlubně). - Geologické výzkumy na Moravě a ve Slezsku, 19, 1-2, 36-41.

Novák, Z. (1975): Spodnobadenské vápence karpatské předhlubně. - MS, kandidátská disertační práce, Přírodovědecká fakulta Univerzity J. E. Purkyně. PřF UJEP Brno.

Otava, J. (1998): Trendy změn ve složení siliciklastik drahanského kulmu a jejich geotektonická interpretace. - Geologické výzkumy na Moravě a ve Slezsku v roce 1997, 5, 62-64.

Paulik, J. (1953): Zpráva o geologickém výzkumu lithothamniových vápenců na Moravě. - Závěrečná zpráva, MS ČGS Brno.

Powers, M. C. (1982): Comparison chart for estimating roundness and sphericity. - AGI Data Sheet 18.

Stráník, Z. (ed.) et al. (1985): Geologická mapa ČR, list 24-43 Šlapanice. - Český geologický ústav. Praha.

Triebold, S. - von Eynatten, H. - Zack, T. (2005): Trace elements in detrital rutile as provenance indicators: a case study from the Erzgebirge, Germany. - Schriftenreihe der Deutschen Gesellschaft für Geowissenschaften, 38, 44-145.

Tucker, M. (ed.) (1988): Techniques in Sedimentology. - Blackwell Science, 1-394.

Walker, R. G. - James, N. P. (1992): Facies Models. Response to sea level changes. - Geological Association of Canada, 1-380, Toronto.

Zack, T. - von Eynatten, H. - Kronz, A. (2004a): Rutile geochemistry and its potential use in quantitative provenance studies. Sedimentary Geology, 171, 37-58.

Zack, T. - Moraes, R. - Kronz, A. (2004b): Temperature dependence of Zr in rutile: empirical calibration of a rutile thermometer. - Contributions to Mineralogy and Petrology, 148, 471-488.

Zágoršek, K. - Nehyba, S. - Tomanová Petrová, P. - Hladilová, Š. - Bitner, M. A. - Doláková, N. - Hrabovský, J. - Jašková, V. (2012): Local catastrophe near Přemyslovice (Moravia, Czech Republic) during Middle Miocene due to the tephra input. - Geological Quarterly, 56, 2, 269-284.

Zborník, V. - Nehyba, S. - Jašková, V. (2013): Výsledky vrtného průzkumu na lokalitě Brus (neogenní sedimenty karpatské předhlubně). - Geologické výzkumy na Moravě a ve Slezsku. 20, 1-2, 63-68. 